\title{
Downregulation of the neonatal Fc receptor expression in non- small cell lung cancer tissue is associated with a poor prognosis
}

\author{
Emilie Dalloneau ${ }^{1,2}$, Nadine Baroukh ${ }^{3}$, Konstantinos Mavridis ${ }^{4}$, Agnès Maillet ${ }^{1,2}$, \\ Fabien Gueugnon ${ }^{1,2}$, Yves Courty ${ }^{1,2}$, Agnès Petit ${ }^{1,2}$, Thomas Kryza ${ }^{5}$, Maguy \\ Del Rio ${ }^{6}$, Serge Guyetant ${ }^{1,2}$, Diana Carolina Cadena Castaneda ${ }^{3}$, Christine \\ Dhommée $^{3}$, Christophe Arnoult ${ }^{3}$, Andreas Scorilas ${ }^{4}$, Valérie Gouilleux-Gruart ${ }^{3,7, *}$, \\ Nathalie Heuzé-Vourc' ${ }^{1,2, *}$ \\ ${ }^{1}$ Université François Rabelais, UMR 1100, Tours, France \\ ${ }^{2}$ INSERM, Centre d'Etude des Pathologies Respiratoires, UMR 1100, Tours, France \\ 3 Université François Rabelais de Tours, CNRS, GICC UMR 7292, Tours, France \\ ${ }^{4}$ Department of Biochemistry and Molecular Biology, University of Athens, Panepistimiopolis, Athens, Greece \\ ${ }^{5}$ Institute of Health and Biomedical Innovation, Translational Research Institute, Queensland University of Technology, \\ Brisbane, Queensland, Australia \\ ${ }^{6}$ Institut de Recherche en Cancérologie de Montpellier (IRCM), INSERM U1194, Montpellier, France \\ ${ }^{7} \mathrm{CHRU}$ de TOURS, Laboratoire d'Immunologie, Tours, France \\ *These authors have contributed equally to this work \\ Correspondence to: Nathalie Heuzé-Vourc'h, email: nathalie.vourch@med.univ-tours.fr \\ Keywords: FCRn, non-small cell lung cancer, prognosis, marker, antitumor immunity \\ Received: October 28, $2015 \quad$ Accepted: May 14, $2016 \quad$ Published: June 15, 2016
}

\section{ABSTRACT}

Lung cancer is the leading cause of cancer-related death worldwide. Although the recommended tumor, node and metastasis (TNM) classification and stage determination are important to select therapeutic options for patients with non-small cell lung carcinoma (NSCLC), additional molecular markers are required to indicate the prognosis, in particular within a specific stage, and help with the management of patients.

Because neonatal Fc receptor (FcRn) has recently been involved in colon cancer immunosurveillance, we measured its expression in non-cancerous and NSCLC lung tissues and evaluated its prognostic value in overall survival for patient with NSCLC. FcRn expression was determined at both mRNA and protein levels on cancerous and adjacent non-cancerous tissues from 80 NSCLC patients. In NSCLC, FcRn was mainly found in resident and tumor infiltrating immune cells. The corresponding mRNA and protein were significantly less abundant in lung tumor than non-cancerous tissue. Moreover, analysis of our cohort and datasets from the public data bases show that FCGRT mRNA down-regulation is a robust and independent, unfavorable predictive factor of NSCLC patient survival. We conclude that FCGRT mRNA expression may be a useful additional marker for immunoscoring, reflecting tumor immune system, and help in the decision-making process for NSCLC patients.

\section{INTRODUCTION}

Lung carcinogenesis is complex, involving both neoplastic cells and the tumor microenvironment. Today, the complex interplay between the immune system and lung tumor is well documented [1]. The quality of antitumor immune responses relies on lymphocytes, macrophages and granulocytes. Cytotoxic $\mathrm{CD}^{+} \mathrm{T}$ lymphocytes (CTL),
$\mathrm{CD}^{+} \mathrm{T}$ lymphocytes, B-lymphocytes and natural killer (NK)/natural killer T (NKT) cells, are known to play a major role in the cytotoxic attack against tumor cells. The success of this attack depends partly on an effective antigen presentation by tumor cells and antigen presenting cells (APC), including macrophages and dendritic cells (DC). As documented in various solid tumors, the nature, the density and the location of immune cells correlate with 
cancer patient prognosis. In non-small cell lung cancer (NSCLC), mature DC and follicular B-cell density, and infiltration of $\mathrm{CD}^{+} \mathrm{T}$ cells correlate with a better clinical outcome [2, 3]. Interestingly, molecular changes, related to antitumor immune response, may also constitute prognosis biomarkers. For example, high expression of calreticulin, which participates to the immunogenic cell death and antigenicity of tumor cells, constitutes a favorable molecular prognosis biomarker in NSCLC [4].

FcRn belongs to the family of receptors for the Fc portion of $\mathrm{IgG}$ and is encoded by FCGRT. FcRn is expressed in many cells and tissues throughout life. It is found in endothelial and epithelial cells from various organs (including placenta, lung, intestine and brain) where it participates in the recycling and transcytosis of $\operatorname{IgG}[5,6]$. This contributes to the long half-life of IgGs in biological fluids and their distribution in the human body [5, 7-9]. Aside from these well-known biological functions, FcRn is also involved in the humoral immune response: present in the epithelia of mucosa, FcRn is important for the host immune response against both bacteria and viruses [10-13]. $\mathrm{FcRn}$ allows virus-specific IgG to bind with pathogens in epithelial cell endosomes where it neutralizes virus [13]. FcRn in immune cells, in particular dendritic cells, macrophages, monocytes [14] and neutrophils [15], is involved in antigen presentation and cross-presentation by dendritic cells $[16,17]$. Recently, FcRn has been shown to play a pivotal role in anti-tumor immunity. Indeed, FcRn mediated tumor protection through DC activation of endogenous tumor-reactive $\mathrm{CD}^{+}-\mathrm{T}$ cells via the crosspresentation of IgG complexed antigens, in a colorectal cancer model, using $f_{c} g r t$ knock-out mice [18]. Moreover, the density of FcRn-expressing DC correlated with $\mathrm{CD}^{+} \mathrm{T}$ cell numbers and predicted improved prognosis in human colorectal carcinoma.

Based on these results, we conducted a retrospective study in several NSCLC cohorts, to evaluate the prognosis value of FcRn expression in lung cancer: the lung is one of the major organs expressing FcRn and lung cancer is the leading cause of cancer-related mortality [19]. Herein, we showed for the first time that FCGRT mRNA is downregulated in non-small cell lung carcinoma (NSCLC) patients and that FCGRT mRNA levels in both NSCLC and adjacent non-cancerous tissues are independently positively correlated with prognosis. We found that FcRn was mainly expressed by resident and tumor-infiltrating immune cells, in the lung, indicating that FCGRT mRNA level might reflect lung antitumor immune response.

\section{RESULTS}

\section{FCGRT mRNA is down-regulated in NSCLC tissue}

FCGRT mRNA was assayed by qRT-PCR in cancerous and non-cancerous samples from patients with
NSCLC (Figure 1A). Mean FCGRT mRNA levels were significantly lower in the cancerous (mean $\pm \mathrm{SE}=0.727$ \pm 0.080 ) than non-cancerous (mean $\pm \mathrm{SE}=2.95 \pm 0.12$ ) tissue. FCGRT mRNA levels were lower in 95\% (76/80) of the NSCLC than paired non-cancerous tissues $(\mathrm{P}<0.001)$. The median FCGRT mRNA values were 6-fold lower in the cancerous than non-cancerous samples (median tumor $=0.482$, median adjacent normal tissue $=2.89 ; \mathrm{P}<$ 0.001) (Figure 1B). Similarly, western blotting of pooled protein extracts from different patients, chosen randomly, showed that the amount of FcRn (normalized to $\alpha$-tubulin) was much lower in cancerous than non-cancerous tissue (Figure 1C). Using a cut-off value of 1.66 expression units, the relative FCGRT mRNA levels in cancerous and non-cancerous tissues showed a sensitivity of $93.7 \%$ and a specificity of $92.5 \%$, (Figure 1D). ROC analysis of FCGRT mRNA levels (Figure 1D) produced a notable AUC of $0.934(\mathrm{SE}=0.024,95 \% \mathrm{CI}=0.884-0.967$, $\mathrm{P}<0.001)$. At fixed sensitivities of $90.0 \%$ and $95.0 \%$, specificity values were $92.50 \%$ and $87.50 \%$, respectively. At fixed specificities of $80.0 \%$ and $90.0 \%$, sensitivity values were $97.50 \%$ and $93.75 \%$, respectively. Findings for stage I specimens were similar: the difference in expression was 5 -fold ( $\mathrm{P}<0.001)$, and the corresponding ROC curve analysis generated an AUC of 0.947 (95\% $\mathrm{CI}=0.905-0.989, \mathrm{P}<0.001$ ) (Figure 1E). Similarly, the discriminatory capacity of FcRn was also robust for stage $>$ I patients $(\mathrm{AUC}=0.923,95 \% \mathrm{CI}=0.862-0.983$, $\mathrm{P}<0.001)$. Using a cut-off value at 1.66 expression units, we can distinguish cancerous tissues from noncancerous with a strong efficiency; this holds true even for early stage (stage I) patients for whom FCGRT mRNA expression analysis offers important differential diagnostic information indicating that it could enhance the accuracy of trans-bronchial needle aspirations or small biopsies. No significant association was found between FCGRT mRNA levels in cancerous tissues and clinic-pathological features (Supplementary Table S1).

\section{Expression of FcRn in NSCLC patients is mainly attributed to immune cells}

The distribution of FcRn protein has been studied in the normal lungs of various species and is restricted to bronchial epithelial cells and alveolar macrophages in humans [20]. NSCLC originate mainly from epithelial bronchial cells (and in some cases from epithelial alveolar cells), so we tested for FcRn expression by immunohistochemistry (see supplemental results for IHC validation) in a small set of cancerous and non-cancerous lung tissues. We detected FcRn in alveolar macrophages and at very low levels in the bronchial epithelium of the noncancerous tissue (Figure 2). In tumor samples, it was very low in neoplastic cells while mainly detected in large cells, located in immune islets, in the stromal and peri-vascular compartment (Figure 2). Staining for CD8 (CD8 ${ }^{+} \mathrm{T}$ cells), 

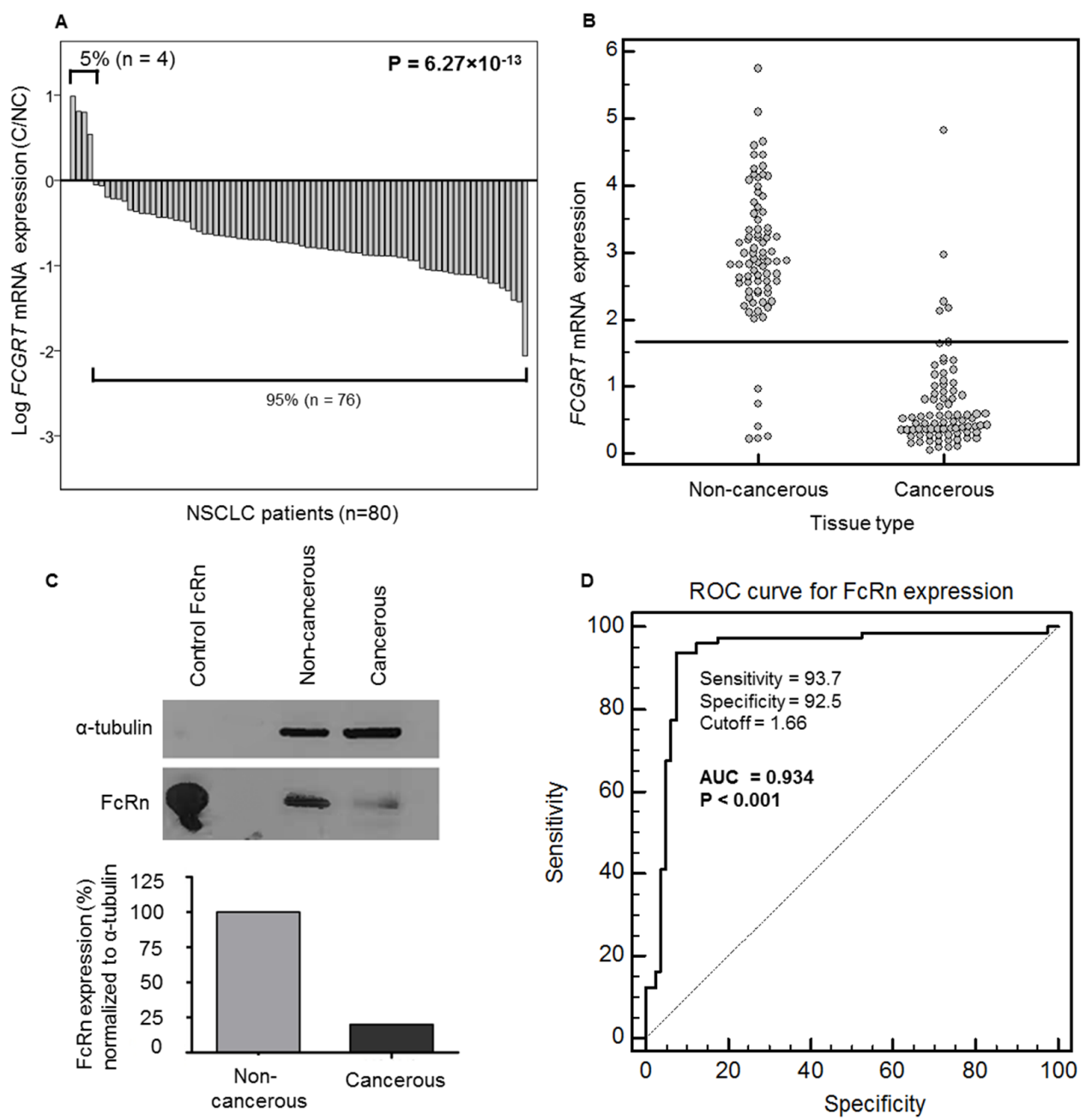

E ROC curve for FCGRT mRNA expression in Stage I patients

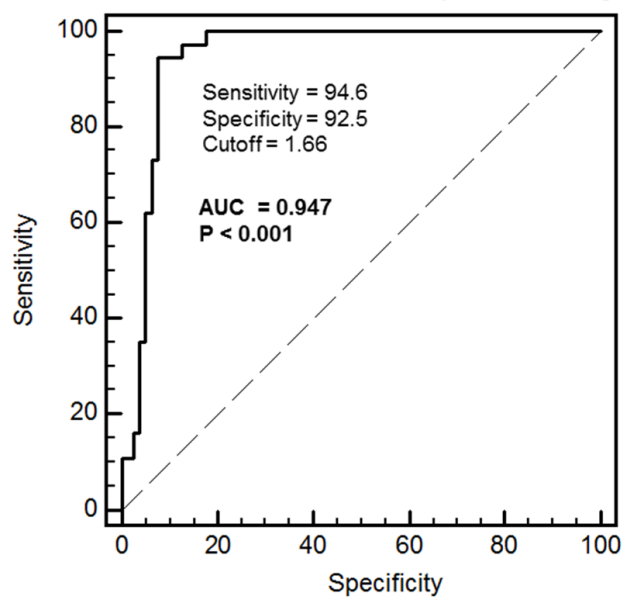

Figure 1: A. Ratios of FCGRT mRNA in cancerous (C) / non-cancerous (NC) in paired tissues from the NSCLC patients $\left(\mathbf{n}=\mathbf{8 0} ; \mathbf{P}=\mathbf{6} .27 \times 10^{-13}\right.$, Wilcoxon Signed Ranks test). B. Distribution of FCGRT mRNA levels in non-cancerous and cancerous tissues $\left(\mathrm{n}=80 ; \mathrm{P}=2.54 \times 10^{-21}\right.$, Mann-Whitney test). C. Representative image of $\mathrm{FcRn}$ protein revealed by western blotting in a pool of 10 patients with matched cancerous and adjacent non-cancerous tissue. Recombinant human FcRn protein was loaded as a positive control. Signals were quantified with ImageJ and normalized to that for $\alpha$-tubulin. D. ROC curve analysis for FCGRT mRNA level in cancerous and noncancerous lung tissue samples. $\mathrm{n}=80, \mathrm{AUC}=0.934, \mathrm{SE}=0.024,95 \% \mathrm{CI}=0.884-0.967, \mathrm{P}<0.0001$, calculations according to DeLong et al., 1988. Youden index $\mathrm{J}=0.863(95 \% \mathrm{CI}=0.775-0.925$, BCa bootstrap interval, 1000 iterations). E. ROC curve analysis for FCGRT mRNA levels in stage I cancerous and in non-cancerous tissues $(\mathrm{n}=37$; $\mathrm{AUC}=0.947,95 \% \mathrm{CI}=0.905-0.989, \mathrm{P}<0.001$, calculations according to DeLong et al., 1988. Youden index $\mathrm{J}=0.871$ ( $95 \% \mathrm{CI}=0.771-0.938$, BCa bootstrap interval, 1000 iterations). 
CD163 (macrophages) or PS100 (dendritic cells) on serial sections revealed that they were macrophages and dendritic cells (Figure 2), as previously described by Baker et al. in human colorectal carcinomas [18].

\section{Prognostic value of FCGRT mRNA in NSCLC patients}

\section{FCGRT mRNA in cancerous tissues is associated with a favorable prognosis}

Baker et al. showed that the frequency of specific FcRn-positive cells correlated with survival in colorectal carcinoma [18], so we evaluated the predictive value of testing for FcRn in cancerous and non-cancerous lung tissues. The predictive value of FcRn for NSCLC patient survival was evaluated by analyzing FCGRT mRNA expression (high or low) in cancer tissues. The survival of NSCLC patients classified as FCGRT-high (62.0 months $(\mathrm{SE}=6.9))$ was better than that of FCGRT-low patients (37.3 months $(\mathrm{SE}=3.3) ; \mathrm{P}=0.046$ Kaplan-Meir analysis) (Figure 3A); this was also shown by univariate Cox regression analysis $(\mathrm{HR}=0.362,95 \% \mathrm{CI}=0.127-1.03$, $\mathrm{P}=0.057$ ) (Table 1). Multivariate Cox regression analysis, adjusted for significant clinicopathological variables, identified FCGRT mRNA expression in the cancerous

A

\section{FcRn in non-cancerous lung}

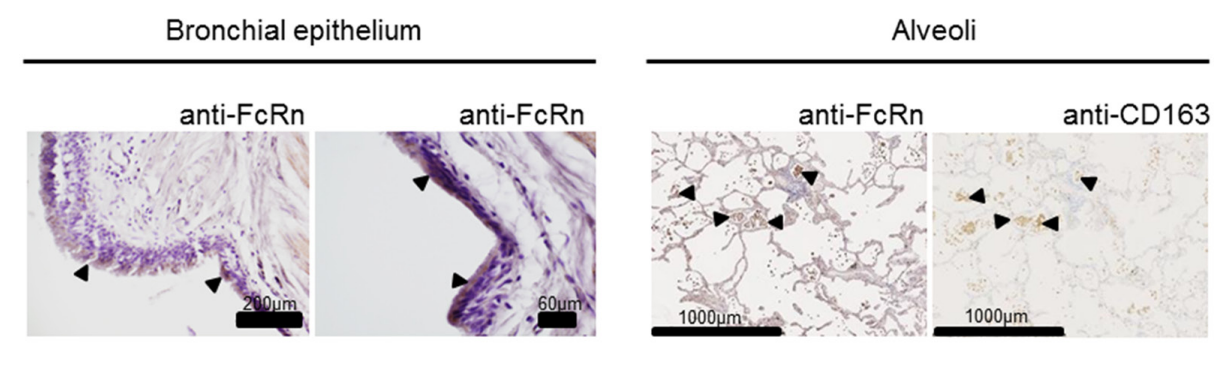

B

FcRn in cancerous lung

Patient 1

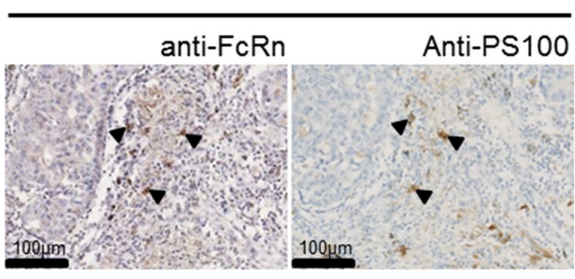

Patient 1

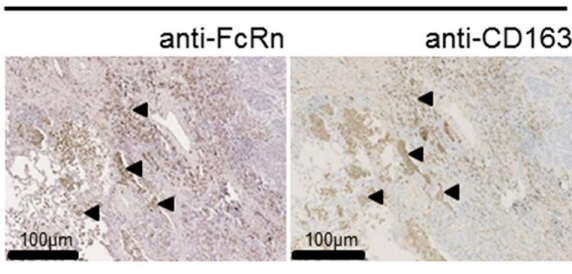

Patient 1

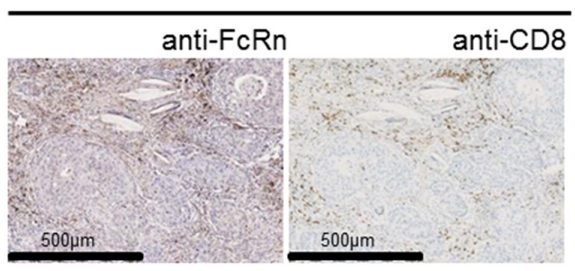

Patient 2

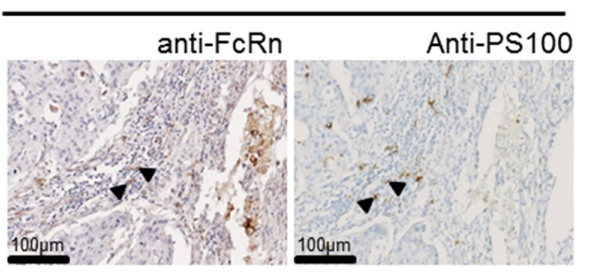

Patient 3

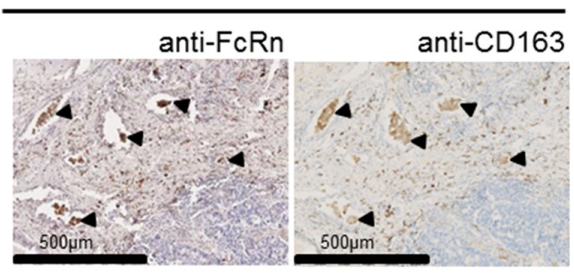

Patient 3

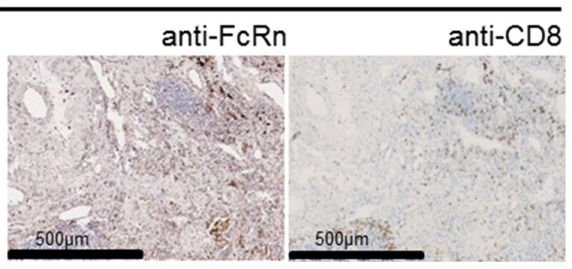

Figure 2: Expression of FcRn in non-cancerous A. and cancerous B. serial lung sections from a small set of patients $(\mathbf{n = 8 )}$. (A) FcRn expression was very week in bronchial epithelial cells (left panel) and marked in alveolar macrophages (right panel) in the non-cancerous lung. (B) In cancerous tissue, the staining revealed that FcRn is expressed in interstitial stromal cells including DCs (PS100), macrophages (CD163) (arrowheads indicate areas of colocalization) but no CD8 ${ }^{+} \mathrm{T}$ cells (CD8). A very weak staining was also observed in carcinomatous cells. Pictures from 3 patients were selected as they are representative of the different staining. 
tissues as an independent indicator of favorable prognosis for NSCLC patients $(\mathrm{HR}=0.332,95 \% \mathrm{CI}=0.112-0.983$, $\mathrm{P}=0.047)$ (Table 1).

\section{FCGRT mRNA in non-cancerous tissues is also an independent predictor of survival for NSCLC patients}

Taking into consideration the recently described role of FcRn in the anti-tumor immune response [18],

\section{A FCGRTMRNA expression in cancerous tissues}
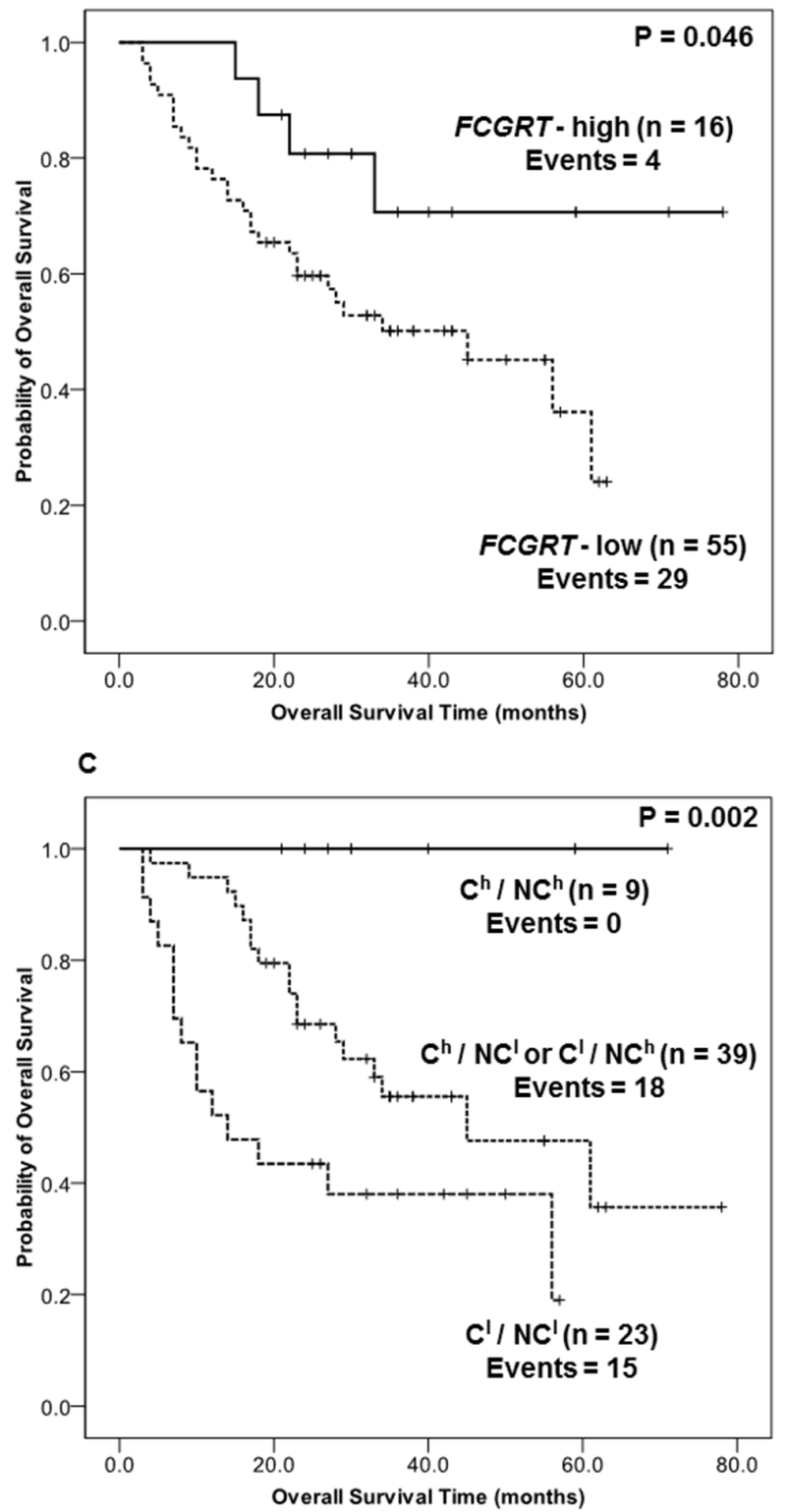

and the prognostic gene expression signatures that can be derived from tumor-adjacent tissue parts as previously reported for several human malignancies [21, 22], we sought to evaluate the predictive value of FCGRT mRNA expression in non-cancerous tissues obtained from NSCLC patients. High FCGRT mRNA levels in the non-cancerous specimens were associated $(\mathrm{P}=$ 0.005 ) with favorable prognosis (Figure $3 \mathrm{~B}$ ), whereas

\section{B FCGRTMRNA expression in non-cancerous tissues}

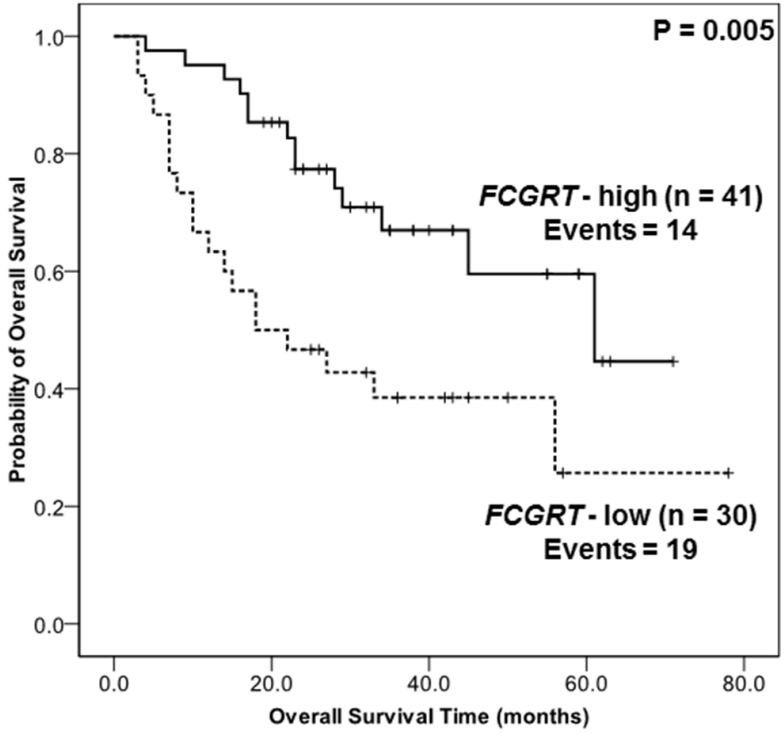

D

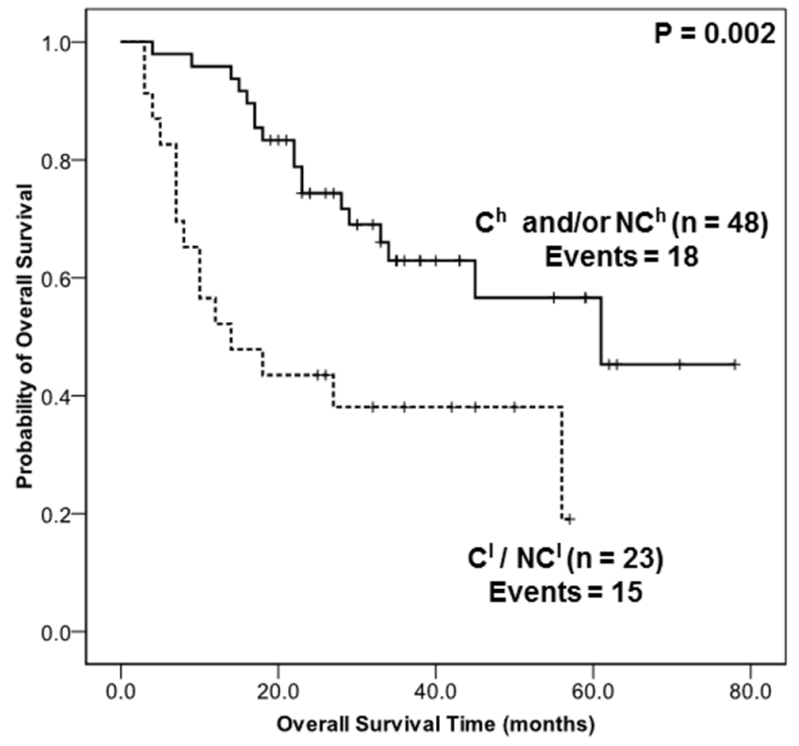

Figure 3: A. Kaplan-Meier overall survival analyses for FCGRT mRNA level in cancerous tissue from NSCLC patients ( $\mathrm{n}=71$ ). Cut-off value $=0.888\left(74^{\text {th }}\right.$ percentile of FCGRT mRNA abundance in cancerous samples). B. Kaplan-Meier overall survival analysis for FCGRT mRNA level in non-cancerous tissue from NSCLC patients $(\mathrm{n}=71)$. Cut-off value $=2.82\left(43^{\text {th }}\right.$ percentile of $F C G R T$ expression in normal tissues). C-D. Kaplan-Meier overall survival analysis for NSCLC patients stratified according to FCGRT mRNA level in cancerous and non-cancerous $(\mathrm{n}=71)$. (C) $\mathrm{C}^{\mathrm{h}} / \mathrm{NC}^{\mathrm{h}}$ : Patients with high FCGRT mRNA levels in both tissue parts. $\mathrm{C}^{\mathrm{h}} / \mathrm{NC}^{\mathrm{l}}$ or $\mathrm{C}^{\mathrm{l}} / \mathrm{NC}^{\mathrm{h}}$ : Patients with high FCGRT mRNA expression only in the cancerous or the non-cancerous tissue, respectively. $\mathrm{C}^{1} / \mathrm{NC}^{1}$ : Patients with low FCGRT mRNA levels in both tissue parts $(\mathrm{n}=71)$. (D) $\mathrm{C}^{\mathrm{h}}$ and/or $\mathrm{NC}^{\mathrm{h}}$ : Patients with high $F C G R T \mathrm{mRNA}$ levels in at least one tissue part (cancer and/or noncancerous tissues n=71). $\mathrm{C}^{\mathrm{l}} / \mathrm{NC}^{\mathrm{l}}$ : Patients with low FCGRT mRNA levels in both tissue parts. Cut-off values as described above. 
Table 1: Cox regression overall survival analyses at the univariate and multivariate levels $(n=71)$

\begin{tabular}{|c|c|c|c|c|c|c|c|c|c|}
\hline \multicolumn{5}{|c|}{ Univariate Analysis } & \multicolumn{5}{|c|}{ Multivariate Analysis } \\
\hline Variable & HR & $95 \%$ CI & $P$ value & $\begin{array}{c}\text { Bootstrap } \\
P \text { value }\end{array}$ & Variable & HR & $95 \% \mathrm{CI}$ & $P$ value & $\begin{array}{c}\text { Bootstrap } \\
P \text { value }\end{array}$ \\
\hline $\begin{array}{l}\text { FCGRT mRNA level } \\
\text { in cancerous tissue }\end{array}$ & & & & & $\begin{array}{c}\text { FCGRT } \\
\text { mRNA level in } \\
\text { cancerous }\end{array}$ & & & & \\
\hline Low (l) $(\mathrm{n}=55)$ & 1.00 & & & & Low & 1.00 & & & \\
\hline High $(h)(n=16)$ & 0.362 & $0.127-1.03$ & 0.057 & 0.041 & \multirow{2}{*}{ High } & $0.332^{\mathrm{a}}$ & $0.112-0.983$ & 0.047 & 0.042 \\
\hline & & & & & & $0.267^{\mathrm{b}}$ & $0.089-0.806$ & 0.019 & 0.013 \\
\hline $\begin{array}{l}\text { FCGRT mRNA level } \\
\text { in non-cancerous } \\
\text { tissue }\end{array}$ & & & & & $\begin{array}{c}\text { FCGRT } \\
\text { mRNA level in } \\
\text { non-cancerous } \\
\text { tissue }\end{array}$ & & & & \\
\hline Low $(n=30)$ & 1.00 & & & & Low & 1.00 & & & \\
\hline $\operatorname{High}(n=41)$ & 0.384 & $0.192-0.769$ & 0.007 & 0.003 & \multirow{2}{*}{ High } & $0.323^{\mathrm{a}}$ & $0.154-0.678$ & 0.003 & 0.002 \\
\hline & & & & & & $0.339^{\mathrm{b}}$ & $0.162-0.709$ & 0.004 & 0.008 \\
\hline $\begin{array}{l}F C G R T \text { mRNA } \\
\text { levels in both tissue } \\
\text { types }\end{array}$ & & & & & $\begin{array}{c}\text { FCGRT } \\
\text { mRNA levels } \\
\text { in both tissue } \\
\text { types }\end{array}$ & & & & \\
\hline $\mathrm{C}^{1} / \mathrm{NC}^{1}(\mathrm{n}=23)$ & 1.00 & & & & $\mathrm{C}^{1 /} \mathrm{NC}^{1}$ & 1.00 & & & \\
\hline $\mathrm{C}^{\mathrm{h}}$ and/or $\mathrm{NC}^{\mathrm{h}}(\mathrm{n}=48)$ & 0.355 & $0.177-0.714$ & 0.004 & 0.003 & $\mathrm{C}^{\mathrm{h}}$ and/or $\mathrm{NC}^{\mathrm{h}}$ & $0.273^{\mathrm{a}}$ & $0.129-0.577$ & 0.001 & 0.001 \\
\hline & & & & & & $0.263^{\mathrm{b}}$ & $0.124-0.556$ & $<0.001$ & 0.002 \\
\hline Stage $(n=71)$ & 1.22 & $1.04-1.44$ & 0.015 & 0.009 & & & & & \\
\hline Histotype & & & & & & & & & \\
\hline $\operatorname{SCC}(n=29)$ & 1.00 & & & & & & & & \\
\hline $\operatorname{ADC}(n=42)$ & 1.23 & $0.605-2.50$ & 0.566 & 0.570 & & & & & \\
\hline Age $(n=71)$ & 0.992 & $0.961-1.02$ & 0.596 & 0.565 & & & & & \\
\hline Metastasis & & & & & & & & & \\
\hline No $(n=57)$ & 1.00 & & & & & & & & \\
\hline Yes $(n=12)$ & 2.37 & $1.09-5.17$ & 0.030 & 0.012 & & & & & \\
\hline
\end{tabular}

${ }^{a}$ Multivariate model adjusted for stage, histotype, age (model a).

${ }^{\mathrm{b}}$ Multivariate model adjusted for metastasis status, histotype, age (model b).

patients with low FCGRT mRNA expression were 2.6 times more likely to die of the disease, as indicated by univariate analysis $(\mathrm{P}=0.007$; Table 1$)$. Furthermore, FCGRT mRNA expression in non-cancerous tissues was found to constitute a strong independent predictor of favorable overall survival outcome in NSCLC patients $(\mathrm{HR}=0.323,95 \% \mathrm{CI}=0.154-0.678, \mathrm{P}=0.003$ Table 1). Altogether those results showed that FCGRT mRNA higher levels in cancerous and, intriguingly noncancerous tissue are associated with a favorable outcome and provide prognosis information independently of other clinic-pathological parameters.
Assessment of FCGRT mRNA in both the tumor and non-cancerous tissues can stratify NSCLC patients according to overall survival

We further stratified NSCLC patients, according to FCGRT mRNA levels in both cancerous (C) and noncancerous (NC) tissue. Overall survival periods were longer for high (h) than low (l) FCGRT mRNA levels in both cancerous and non-cancerous tissues $(\mathrm{P}=0.002)$ (Figure 3C-3D). Strikingly, none of the "double high" $\left(\mathrm{C}^{\mathrm{h}}\right.$ $/ \mathrm{NC}^{\mathrm{h}}$ ) patients died during the follow-up period, whereas the survival probabilities progressively worsened over time for patients with one or both tissue types scored as 
FCGRT-low (Figure 3C). The findings were similar when the patients were grouped into those with high FcRn expression in at least one tissue type $\left(\mathrm{C}^{\mathrm{h}}\right.$ and/or $\left.\mathrm{NC}^{\mathrm{h}}\right)$ and those with low FCGRT expression in both tissue types $\left(\mathrm{C}^{1 / 2} \mathrm{NC}^{1}\right)$ : the latter group showed significantly worse outcomes $(\mathrm{P}=0.002)$ (Figure $3 \mathrm{D})$.

Thus, analysis of FCGRT mRNA expression in both tissues types can provide significant and robust prognostic information about NSCLC patients as shown by univariate Cox regression $(\mathrm{HR}=0.355,95 \% \mathrm{CI}=0.177$ $-0.714, \mathrm{P}=0.004$ ) (Table 1 ), which is independent of the currently used conventional indicators and important clinico-pathological variables as proven by multivariate survival analysis $(\mathrm{HR}=0.273,95 \% \mathrm{CI}=0.129-0.577$, $\mathrm{P}=0.001)$ (Table 1).

\section{Prognostic value of $F C G R T$ mRNA in early stage and in metastasis-free NSCLC patients}

We analyzed the prognostic performance of FCGRT mRNA levels in subgroups of NSCLC patients conventionally classified as "lower-risk". Kaplan-Meier survival analysis within the early stage (I/II) patient subgroup indicated that high FCGRT mRNA levels retained their association with favorable outcome; this was statistically significant for non-cancerous tissue $(\mathrm{P}=0.035)$. Early stage patients with high levels of FCGRT mRNA in at least one tissue $\left(\mathrm{C}^{\mathrm{h}}\right.$ and/or $\left.\mathrm{NC}^{\mathrm{h}}\right)$ survived longer than patients with low levels of FCGRT mRNA in both tissues $\left(\mathrm{C}^{\mathrm{l}} / \mathrm{NC}^{\mathrm{l}}\right)(\mathrm{P}=0.055)$. Similar observations were made for the non-metastatic patients, as FCGRT mRNA expression again endowed NSCLC patients with enhanced overall survival intervals; this held true for the determination of FCGRT mRNA expression in non-cancerous tissue parts $(\mathrm{P}=0.007)$ and the comparisons between NSCLC patients with at least one tissue part with a high expression versus patients with both tissue having a low expression of FCGRT mRNA $(\mathrm{P}=0.008)$ (see Supplementary Table S2).

Multivariate analysis confirmed the independent prognostic information from FCGRT mRNA expression levels in normal and cancerous tissues, further demonstrating the similar yet discrete clinical significance of these assessments (data not shown).

\section{Prognostic value of FCGRT mRNA expression is validated in others cohorts with NSCLC}

In order to reinforce our findings regarding the prognostic significance of FCGRT mRNA expression in lung cancer, we performed in silico analysis of FcRn expression. Firstly, we analyzed microarrays studies extracted from the Oncomine database [23]. The results showed that FCGRT mRNA down regulation was also associated with poor survival of NSCLC patients in several datasets, supporting the results of our qRT-PCR study (Tables 2 and 3). Secondly, we used Affymetrix microarray expression data from lung cancer patients and analyzed FCGRT mRNA expression as determined by probe set 218831_s_at, based on the online "Kaplan Meier Plotter" tool [24]. The significant association of FCGRT mRNA expression with favorable overall survival of lung cancer patients that we observed, was validated using this independent dataset of 1,926 lung cancer samples (Figure 4A, see Supplementary Table S3) at the univariate $(\mathrm{HR}=0.69,95 \% \mathrm{CI}=0.6-0.79, \mathrm{P}=$ $\left.8 \times 10^{-8}\right)$, and multivariate levels after adjustment for stage and tumor histotype $(\mathrm{HR}=0.69,95 \% \mathrm{CI}=0.55-086, \mathrm{P}=$ 0.0009) (see Supplementary Table S3). Finally to validate these results, we performed a meta-analysis on data from publicly available expression analysis platforms: Kaplan Meier Plotter [24], PrognoScan [25], PROGgeneV2 [26] and SurvExpress [27]. FCGRT mRNA expression was strongly associated with favorable overall survival of lung cancer patients as indicated by the pooled HR from $\mathrm{n}=31$ studies $/$ databases $\mathrm{HR}=0.70(95 \% \mathrm{CI}=0.65-0.74)$, $\mathrm{P}<0.0001$. In $28 / 31$ studies the HRs were $<1$ (indicating association with favorable prognosis) and $12 / 31$ were individually statistically significant, including large cohorts from the Kaplan Meier plotter database $(\mathrm{N}=1926)$, the SurvExpress platform $(\mathrm{N}=1044)$ and the CAARAY, NCI $(\mathrm{N}=468)$ (Figure 4B, see Supplementray Table S4). Moreover, no statistical heterogeneity was observed (Cochran $\mathrm{Q}=33.08, \mathrm{df}=30, \mathrm{P}=0.3191, \mathrm{I}^{2}=$ $9.3 \%, 95 \% \mathrm{CI}=0-42 \%$ ), neither statistically significant bias (Begg-Mazumdar: Kendall's tau $=0.0409 \mathrm{P}=$ 0.7616, Egger: bias $=-0.04965,95 \% \mathrm{CI}=-0.790-0.691$, $\mathrm{P}=0.8918$ ) (Figure 4C, see Supplementary Table S4). The absence of statistically significant heterogeneity and bias are indicators of the sufficient quality of the metaanalyses and the validity of the deriving conclusions.

\section{DISCUSSION}

The lungs are one of the major organs expressing FcRn and a common site of carcinogenesis. In this study, we showed a significant decrease of FcRn expression, at both the mRNA and protein levels, in the lung cancerous compared to the lung non-cancerous tissues from NSCLC patients. This discriminative value of FCGRT mRNA expression between cancer lesions from non-cancerous tissue parts is high, even for early stage patients (AUC $=0.947)$. This result is in line with the recent evidences demonstrating a central role of FcRn in anti-tumor immune-surveillance [18]. It also raises questions on the role of FcRn in non-cancer lung diseases, since lower levels of FCGRT mRNA were also described in bronchiectasis and lung fibrosis, correlating with the extent of lung abnormalities [28].

Herein, we also found that FCGRT mRNA levels were associated with a favorable outcome and provided prognostic information independently from important clinic-pathological parameters, when it was assessed in the cancer or, intriguingly, in the non-cancerous tissue part. In fact, FCGRT mRNA expression, especially 
Table 2: Association between survival status and down-regulation of FCGRT mRNA expression in some human lung cancer datasets extracted from Oncomine

\begin{tabular}{lccc}
\hline $\begin{array}{l}\text { Clinical parameters significantly associated to reduced } \\
\text { FCGRT mRNA levels in human Lung cancer datasets }\end{array}$ & n & p-value & Dataset Reference \\
\hline Lung Adenocarcinoma, Dead at 1 Year & 76 & 0.03 & Beer Lung, Nat Med, 2002 \\
Large Cell Lung Carcinoma, Dead at 3 Years & 21 & 0.014 & Garber Lung, Proc Natl Acad Sci U \\
S A, 2001 & 10 & 0.016 & Zhu Lung, J Clin Oncol, 2010 \\
Large Cell Lung Carcinoma, Dead at 5 Years & 12 & 0.012 & Hou Lung, PLoS One, 2010 \\
Squamous Cell Lung Carcinoma, Dead at 5 Years & 10 & 0.016 & Zhu Lung, J Clin Oncol, 2010 \\
\hline
\end{tabular}

Table 3: Associations between FCGRT mRNA expression and survival status of NSCLC patients at 1 year after surgery (Tours' hospital cohort)

\begin{tabular}{lccc}
\hline FCGRT expression & \multicolumn{2}{c}{ Number of patients (\%) } & $\mathbf{P}^{*}$ \\
\cline { 2 - 3 } & \multicolumn{2}{c}{ 1-year survival } & \\
\hline Cancerous tissue & Dead & Alive & 0.032 \\
Low (1) & $13(100.0)$ & $42(72.4)$ & \\
High (h) & $0(0.0)$ & $16(27.6)$ & \\
Non-cancerous tissue & Dead & Alive & \\
Low & $11(84.6)$ & $19(32.8)$ & 0.001 \\
High & $2(15.4)$ & $39(67.2)$ & \\
Combined & Dead & Alive & \\
$\mathrm{C}^{1} / \mathrm{NC} \mathrm{C}^{1}$ & $11(84.6)$ & $12(20.7)$ & $<0.001$ \\
$\mathrm{C}^{\mathrm{h}}$ and/or NC & $2(15.4)$ & $46(79.3)$ & \\
\hline
\end{tabular}

*Fisher's exact test

when assessed in the non-cancerous tissue part has prognostic relevance even for the "lower-risk" early stage $(\mathrm{P}=0.035)$ and metastasis-free NSCLC patients $(\mathrm{P}=0.007)$. Interestingly, multivariate analysis also corroborated the similar yet discrete clinical significance of these assessments (data not shown). Overall our findings are consistent with the accumulating evidences showing molecular alterations of the normal-appearing tissue adjacent to tumor lesions and their impact in the stepwise progression to lung cancer [29]. Considering the role of FcRn in immunosurveillance and tumorigenesis, the decrease in FCGRT mRNA expression might be an important biomarker of the molecular changes promoting lung carcinogenesis and tumor progression. It may help with decision-making for NSCLC management and yield important advances for the development of novel chemoprevention strategies.
When analyzing the combined non-cancerous and cancerous expression of FCGRT mRNA, we noticed a progressive deterioration of overall survival periods with the decrease presence of FCGRT mRNA in non-cancerous and cancerous tissue parts. None of the patients classified as FCGRT mRNA -high for both tissue parts died within the study's follow-up period, whereas the survival probabilities worsened when moving to patients with one tissue part and both tissue parts showing low expression. This observation extends the tumor-protective role of FcRn in the lungs. The combined analysis of FCGRT mRNA expression can provide significant and robust prognostic information regarding the overall survival of NSCLC patients. The robustness of our findings is clearly reinforced by the fact that same results were found in other independent and international cohorts. It was found to be independent 

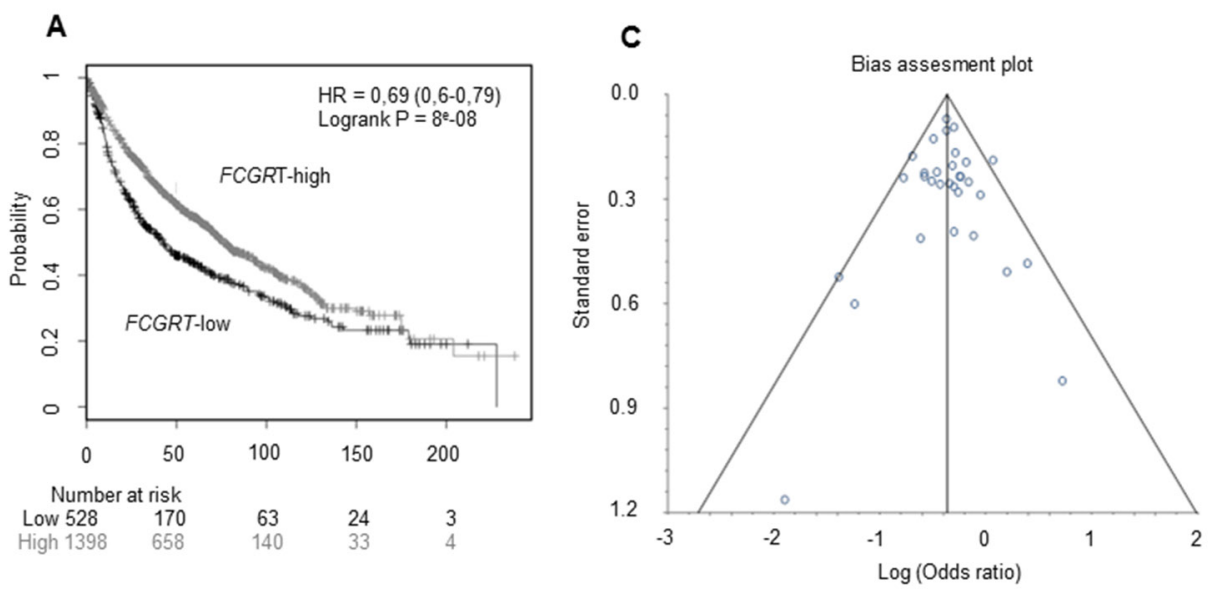

B

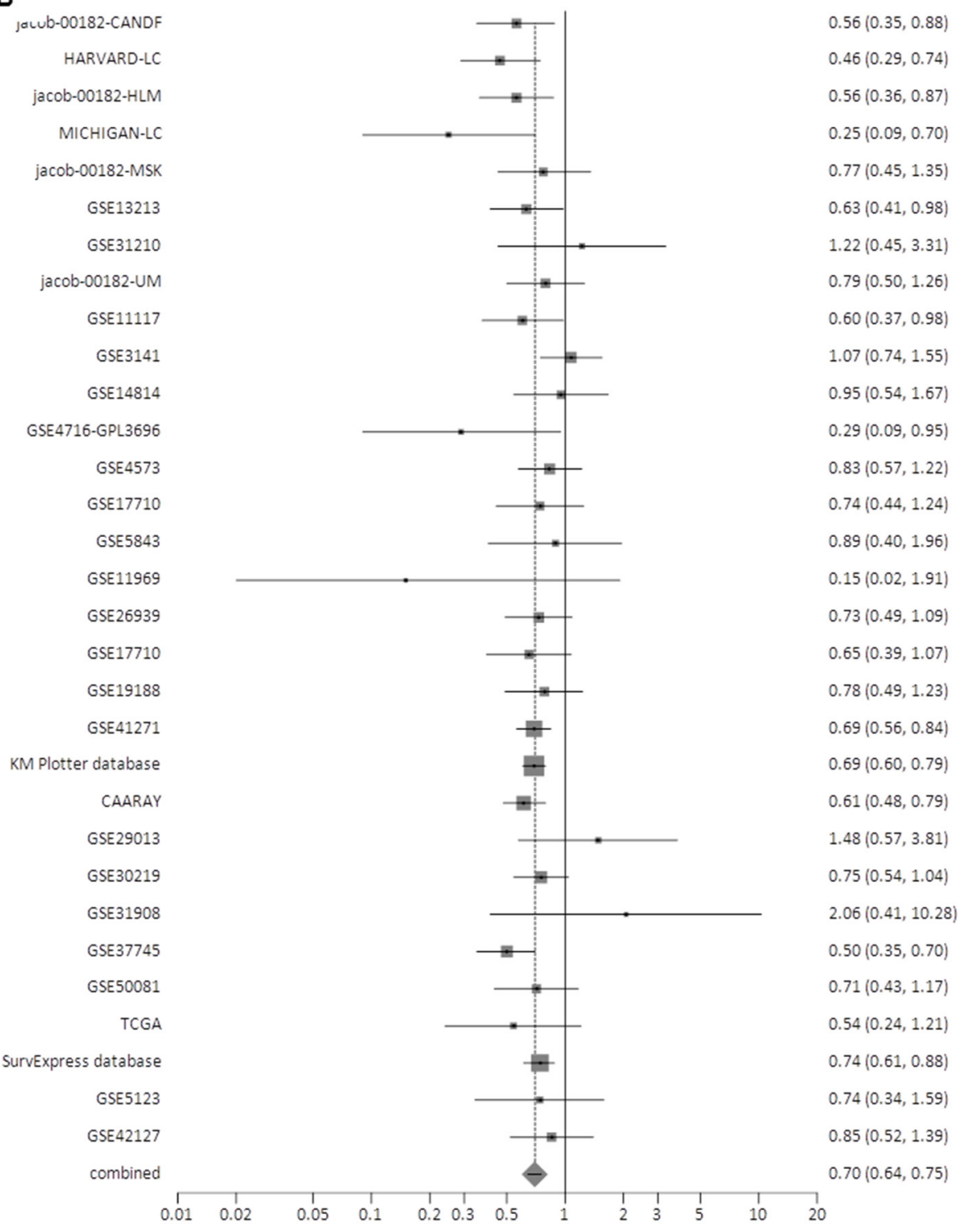

Figure 4: A. Kaplan-Meier overall survival curves based on FCGRT expression (high vs low), as assessed by the KM plotter expression analysis data. B. Forest plot (random effects method) of the hazard ratio for $F C G R T$ expression and overall survival in lung cancer based on data obtained by the PrognoScan, PROGgeneV2, Kaplan Meier Plotter and SurvExpress platforms. C. Bias assessment plot for trials considered in the meta-analysis. 
of the currently used conventional indicators and important clinic-pathological parameters. Moreover, these results were confirmed by the meta-analysis realized on data from publicly available microarray databases. In fact, the absence of statistically significant heterogeneity and bias in the meta-analysis are indicators of the sufficient quality of the meta-analyses and the validity of the deriving conclusions.

Description of FcRn expression in a small set of patients, by IHC, revealed a marked expression by alveolar macrophages and a faint signal from epithelial bronchial cells in the normal lungs, as previously described [20]. In NSCLC, FcRn expression was mainly found in infiltrating immune cells, in particular macrophages and DCs. Further studies will be required to assess if FCGRT mRNA reduction is attributed to a lower density of $\mathrm{FcRn}^{+}-$ cells or/and to molecular mechanisms underlying mRNA down-regulation in these cells. In colorectal carcinoma, Baker et al. [18] found that FcRn-positive dendritic cells (DCs) were strongly correlated with the presence of $\mathrm{CD}^{+}$ $\mathrm{T}$ cells in the non-cancerous tissue and promote the antitumor role of FcRn. In NSCLC, the global expression of FCGRT mRNA might be a reflection of the density of antigen presenting cells and antitumor immune response in NSCLC. In that context, it will be interesting to evaluate the predictive value of FcRn in response to immunomodulatory monoclonal antibodies, targeting immune checkpoints (anti-PD-1 or anti-CTLA-4) that have raised great promises in the treatment of NSCLC $[30,31]$.

Although the recommended tumor, node and metastasis (TNM) classification and stage determination are important to select therapeutic options for patients with non-small cell lung carcinoma (NSCLC), additional molecular markers are required to indicate better the prognosis, in particular within a specific stage, and determine the potential benefits of adapted therapy in NSCLC [32]. We report the first demonstration of the prognostic and predictive values of testing for FCGRT mRNA in NSCLC patients. The prognostic value of testing for FcRn in specific cell populations by double IHC staining has already been described in colorectal carcinoma [18]. Although our study suffers from the common limitations of investigations with surgical tumor samples, being mainly descriptive, as well as a retrospective nature and a certain degree of heterogeneity of the samples, our results identified FCGRT mRNA level as a robust and independent marker of NSCLC patient outcome and add to the existing evidences on the central role of the tumor's niche on carcinogenesis and disease progression [33]. Future external validations, in one or more independent, ideally multicentric, prospective studies would be required to support our findings and help transfer our results to a clinical application for NSCLC.

Testing for FCGRT mRNA is straightforward, and can readily be applied in the clinic. This novel marker could be combined with the recently described Immunoscore ${ }^{\circledR}[34]$, a method measuring the beneficial impact of the immune infiltrate on tumor outcome, which has emerged in colorectal cancer and may be relevant in other malignancies, such as lung cancer [35]. Taking together, they may help with decision-making for NSCLC management, contributing to the timely and appropriate administration of adjuvant treatment.

\section{MATERIALS AND METHODS}

\section{Lung tissue specimens}

Specimens $\left(2-3 \mathrm{~cm}^{2}\right)$ of cancerous and noncancerous tissues ( 80 patients) were collected from patients prior to any therapy, as described by Gueugnon et al. [36] at the Trousseau Hospital, Tours, France, between 2006 and 2011 ( ${ }^{\circ}$ DC-2008-308 - also named in the manuscript Tours' hospital cohort). The nonmalignant tissue samples were taken from sites at least $3 \mathrm{~cm}$ away from the edge of the tumor. Patient data were recorded in a database for statistical analysis (See Tables 4 and 5). This study was conducted in accordance with the ethical standards of the Helsinki Declaration and French bioethical authorities. Frozen lung tissues were embedded in Tissue-Tek OCT (Sakura Finetek Europe) and $8 \mu \mathrm{m}$ sections were cut on a cryotome (Thermo SCIENTIFIC). Sections (up to $50 \mathrm{mg}$ ) were immediately placed in lysis buffer (RLT Plus, Qiagen) containing 143 $\mu \mathrm{M} \beta$-mercaptoethanol and vortexed thoroughly for 2 minutes. The lysates were then centrifuged in a microfuge for $1 \mathrm{~min}$ at full speed. Aliquots of each supernatant were collected and stored at $-80^{\circ} \mathrm{C}$. RNA was purified on a QIAsymphony SP workstation using the RNA CT 400 protocol (QIAsymphony RNA kit, Qiagen), including digestion of genomic DNA with DNAse I. Total RNA was eluted RNAse-free water and quantified using a NanoDrop 2000c spectrophotometer (Thermo SCIENTIFIC). RNA integrity was assessed using an Agilent 2100 bioanalyzer. Only samples with an RNA integrity number (RIN) > 6 were considered for RT-qPCR analysis ( 80 patients matched for tumoral and non tumoral adjacent tissue).

Single-strand cDNA was synthesized from $2 \mu \mathrm{g}$ total RNA from each sample with the High Capacity cDNA Reverse Transcription kit (Applied Biosystems), according to the manufacturer's instructions.

\section{Quantitative real-time PCR}

Following RNA extraction from NSCL and non-cancerous adjacent tissues, and cDNA synthesis, quantitative-PCR was carried out on the LightCycler 480 (Roche Diagnostics $\mathrm{GmbH}$ ) as described by Gueugnon et al. [36]. The concentration of FCGRT mRNA was normalized to the geometric mean of mRNAs of two reference genes: TATA-binding protein 
Table 4: Patient characteristics $(n=80)$

\begin{tabular}{|c|c|}
\hline Characteristics & $\mathbf{N}(\%)$ \\
\hline \multicolumn{2}{|l|}{ Gender } \\
\hline Male & $64(80)$ \\
\hline Female & $16(20)$ \\
\hline \multicolumn{2}{|l|}{ Smoking history } \\
\hline Never & $9(11.25)$ \\
\hline Former/Current & $68(85)$ \\
\hline Unknown & $3(3.75)$ \\
\hline \multicolumn{2}{|l|}{ Histologic type } \\
\hline $\begin{array}{l}\text { Squamous cell carcinoma } \\
\text { (SCC) }\end{array}$ & $35(43.75)$ \\
\hline Adenocarcinoma (ADC) & $45(56.25)$ \\
\hline \multicolumn{2}{|l|}{ T- primary tumor size } \\
\hline$\leq 3 \mathrm{~cm}$ & $27(33.75)$ \\
\hline$>3 \mathrm{~cm}$ & $48(60)$ \\
\hline Unknown & $5(6.25)$ \\
\hline \multicolumn{2}{|l|}{ N-lymph node status } \\
\hline Yes & $47(58.75)$ \\
\hline No & $31(38.75)$ \\
\hline Unknown & $2(2.5)$ \\
\hline \multicolumn{2}{|l|}{ M- distant metastasis } \\
\hline Yes & $13(16.25)$ \\
\hline No & $65(81.25)$ \\
\hline Unknown & $2(2.5)$ \\
\hline \multicolumn{2}{|l|}{ pTNM Stage } \\
\hline IA & $11(13.75)$ \\
\hline IB & $26(32.5)$ \\
\hline IIA & $5(6.25)$ \\
\hline IIB & $8(10)$ \\
\hline IIIA & $13(16.25)$ \\
\hline IIIB & $3(3.75)$ \\
\hline IV & $13(16.25)$ \\
\hline Unknown & $1(1.25)$ \\
\hline
\end{tabular}

$(T B P)$ and hypoxanthine phosphoribosyltransferase 1 (HPRT1). This gives more reliable results than using a single reference gene [37]. Gene-specific primer pairs were designed according published mRNA sequences so that the amplicons generated spanned two exons. The sequences of the primers used in this study are:
FCGRT F 5'-CCCTGGCTTTTCCGTGCTT-3'; R 5'-TGACGATTCCCACCACGAG-3'; HPRT1 F 5'-CAT TATGCTGAGGATTTGGAAGG-3'; R 5'-CTTGAGCAC ACAGAGGGCTACA-3'; TBP F 5'-TGTATCCACAG TGAATCTTGGT TG-3'; R 5'-GGTTCGTGGCTCTCT TATCCTC-3'. PCR reactions were carried out using 20ng cDNA as template, $0.2 \mu \mathrm{M}$ each of forward and reverse primer and 1x SYBR Premix Ex Taq (Takara Bio Inc). Each reaction was performed in triplicate. The thermal protocol consisted of an initial denaturation step at $95^{\circ} \mathrm{C}$ for $30 \mathrm{sec}$ followed by 40 cycles of denaturation at $95^{\circ} \mathrm{C}$ for $5 \mathrm{sec}$ and primer annealing and extension at $60^{\circ} \mathrm{C}$ for $20 \mathrm{sec}$. Melting curves were generated for each amplified cDNA to check the specificity of the reactions. In the standard protocol, fluorescence was read at $60^{\circ} \mathrm{C}$ during the annealing and extension step. However, we included an additional step (heating at $82^{\circ} \mathrm{C}$ for $15 \mathrm{sec}$ ) to record the fluorescence. This increased the specificity of FCGRT measurement by eliminating all non-specific signals. Each PCR run included a no-template control and a calibrator AV090211 (a pool of cDNA from many lung tumors) to evaluate inter-assay variability.

Serial dilutions of the AV090211 calibrator (a pool of 10 cDNA from tumoral and non tumoral samples) (80ng cDNA to $0.625 n g$ cDNA) were used to create a standard curve for each gene. These curves were constructed by plotting the crossing point $(\mathrm{Cp})$ values against the initial quantity of the AV090211 calibrator. The Cp of a sample, defined as the point where the fluorescence curve of the sample was above the background fluorescence, was calculated according to the second derivative maximum method by the LightCycler 480 software. The efficiencies of PCR for $\mathrm{t} F C G R T$ and reference genes were calculated from the formula $\mathrm{E}=10^{-1 / \text { slope }}$; they were close to $100 \%$ (i.e. efficiency $\mathrm{E}=2$ ): FCGRT: $\mathrm{E}=1.986 ; T B P: \mathrm{E}=$ 2.041; HPRT1: $\mathrm{E}=1.979$. Thus, the software converted $\mathrm{Cp}$ data from the samples into a concentration for each gene using the PCR efficiency and the initial amount of AV090211 calibrator. Finally, the results for each sample were normalized by dividing the FCGRT value by the geometric mean of HPRT1 and TBP reference genes.

\section{Western blot}

Protein extracts $(40 \mu \mathrm{g})$ of a pool of 10 cancerous tissues and 10 matched non-cancerous tissues from NSCLC patients, chosen blindly and human recombinant FcRn protein were separated on a NUPAGE 4-12\% Bis-Tris gel (Life Technologies) and then transferred onto PVDF (polyvinyldenedifluoride) membranes by electroblotting. Membranes were blocked and then incubated with anti-FcRn (1/500) (Novus Biologicals cat. number NBP1-89128) or anti-alpha tubulin (1/20000) as a loading control antibody (Abcam cat. number ab7291) under the conditions recommended by the manufacturers. After incubation with the appropriate conjugated-HRP 
Table 5: Descriptive statistics of the continuous variables $(n=80)$

\begin{tabular}{lcccccccccc}
\hline & \multicolumn{1}{c}{} & \multicolumn{1}{c}{ Percentiles } \\
\cline { 2 - 11 } & $\mathbf{N}$ & Mean & S.E. & Min & Max & $\mathbf{1 0}$ & $\mathbf{2 5}$ & $\begin{array}{c}\mathbf{5 0} \\
\text { (median) }\end{array}$ & $\mathbf{7 5}$ & $\mathbf{9 0}$ \\
\hline Age & 80 & 65.2 & 1.2 & 36.0 & 83.0 & 50.2 & 59.0 & 66.5 & 73.0 & 78.0 \\
Tumor size (cm) & 75 & 3.75 & 0.18 & 1.20 & 10.0 & 2.00 & 2.50 & 3.50 & 4.50 & 6.00 \\
Packs per year & 66 & 42.8 & 2.4 & 5.0 & 100 & 20.0 & 30.0 & 40.0 & 50.0 & 75.0 \\
Smoking cessation & 57 & 7.32 & 1.50 & 0.0 & 60.0 & 0.0 & 0.0 & 0.0 & 11.5 & 22.4 \\
(years) & & & & & & & & & & \\
OS (months) & 71 & 30.0 & 2.14 & 3.0 & 78.0 & 7.0 & 17.0 & 27.0 & 42.0 & 58.6 \\
\hline
\end{tabular}

secondary antibody, membranes were developed using an enhanced chemiluminescence western blotting detection reagent (Amersham Biosciences). Densitometry of the FcRn spots was quantified using ImageJ and normalized with $\alpha$-tubulin. The experiments were done three times with two different pools of proteins from 10 patients. The FcRn human recombinant protein used as a positive control is homologous over its entire region to the amino acid sequence PAKS, from there it is deleted on the entire $\mathrm{Ct}$ final region and the original sequence was replaced by a synthetic sequence which corresponds to the sequence factor X, followed by the V5 epitope and a polyhistidine. The construction has been obtained by a 2 -step cloning 1 ) a deletion from PAKS (since the beginning of exon 6) then 2) an insertion of the synthetic sequence at BamHI-NotI site.

\section{Immunohistochemical analysis}

Staining of $\mathrm{FcRn}^{+}$- cells, dendritic cells, macrophages and $\mathrm{CD} 8^{+}-\mathrm{T}$ cells was assessed on both cancerous (C) and non-cancerous (NC) $3 \mu \mathrm{m}$-thick serial lung tissue sections from a small set of patients $(\mathrm{n}=8)$, using anti-FcRn (Abcam cat. number ab4360), anti-PS100 (Dako, cat. number Z0311), anti-CD163 (LEICA, cat. number NCL-CD163) and anti-CD8 (Dako, cat. number M7103) antibodies, respectively. Briefly, tissues were deparaffinized, rehydrated and subjected to heat antigen retrieval in a citrate buffer (pH 6.0). FcRn staining was done as followed: samples were washed twice in TBS-Tween $0.1 \%$ before being blocked for endogenous peroxidase activity in $3 \%$ hydrogen peroxide-methanol. After 2 washes, the VECTASTAIN Elite ABC Kit (Goat IgG, VECTOR Laboratories) was used for immunostaining following the manufacturer's instructions. Tissues sections were blocked $1 \mathrm{~h}$ in blocking buffer (PBS-triton $0.4 \%+3$ drops of goat sera (from the VECTASTAIN Elite ABC kit) + 5\% BSA + 3\% normal human sera buffer). Tissue sections were incubated with anti-FcRn (diluted 1/500) polyclonal antibody (Novus Biologicals cat. number NBP1-89128) overnight at $4{ }^{\circ} \mathrm{C}$ in blocking buffer. A standard avidin-biotin immunoperoxidase method and diaminobenzidine as chromogen (DakoCytomation) were used for visualization. Tissues slides were colored using Harris' hematoxylin. Rabbit IgG $(1 / 28,000)$, whole molecule (Jackson ImmunoResearch), was used as both isotype and negative control. Positive and negative controls were realized on human placenta section with FcRn antibody. PS100, CD163 and CD8 staining were done using a benchmark XT automated stainer (Roche) following the manufacturer's instructions; tissues sections were colored with Gill's hematoxylin.

\section{Statistical analyses}

Differences between FCGRT expression values between groups of cancerous samples were assessed using the non-parametric Mann-Whitney $U$ and JonckheereTerpstra tests. FCGRT mRNA levels in paired NSCLC samples were compared with the non-parametric Wilcoxon signed-rank test. The DeLong et al. [38] method was used for ROC curve analyses. The optimal cut-off that derived from the ROC curve analysis corresponded to the highest accuracy as calculated by the Youden index $\mathrm{J}$.

Kaplan-Meier survival curves were analyzed for the overall survival of the 71 NSCLC patients with available follow-up data; the log-rank test was used for evaluation of statistical significance. Cox regression models were used to evaluate the prognostic potential of FCGRT mRNA levels for overall survival (OS) of NSCLC patients through the calculation of hazard ratios (HR) at the univariate and multivariate levels. Multivariate models were adjusted for tumor stage, tumor histotype and patient age (model a) or metastasis status, tumor histotype and patient age (model b). For survival analyses, optimal cutoff points were established using the X-tile algorithm and the minimal $\mathrm{p}$-value approach for cutoff optimization. All regression models were validated by the bootstrap resampling ( $\mathrm{n}=1,000$ bootstrap samples) using the bias corrected and accelerated approach. The selected cut-off for FcRn expression in the cancerous tissue parts was additionally validated $(\mathrm{P}=0.0197)$ in the Kaplan-Meier Plotter (KM Plotter) database, indicating that it can be applied in an independent dataset. SPSS Statistics (version 17.0), MedCalc software (version 12.5) and GraphPad Prism (version 5.00) were used. 


\section{Publicly available databases, online survival analysis tools and meta-analysis}

The Oncomine database and gene microarray analysis tool, a repository for published cDNA microarray data (www.oncomine.org) [23] was used (January 2015) to analyze the FCGRT mRNA expression in public Lung cancer datasets [39-42]. Oncomine algorithms were used for the statistical analysis of the differences in FCGRT mRNA expression and association with patient survival status (Student's t-test).

The Kaplan Meier-Plotter (KM Plotter) online survival analysis tool was used in order to confirm the prognostic potential of FcRn in a large cohort of lung cancer patients. Briefly, gene expression data and overall survival information are downloaded from GEO, EGA and TCGA and a database is created. To analyze the prognostic value of a particular gene, in our case FCGRT, the patient samples are split into two groups according to various quantile expressions and are compared by a Kaplan-Meier survival plot. KM plotter was used both at the univariate and multivariate level [24].

Meta-analysis on FcRn prognostic significance was performed by gathering all available Hazard Ratios and 95\% Confidence Intervals for FcRn in lung cancer from different individual microarray-based studies using the publicly available biomarker analysis and validation tools: Prognoscan [25], ProgGene V2 [26], SurvExpress [27] and KM Plotter [24]. Subsequently we analyzed this information with the StatsDirect v3.0 [StatsDirect Ltd. StatsDirect statistical software. http://www.statsdirect. com. England: StatsDirect Ltd. 2013]. Statistical software in order to calculate the pooled Hazard Ratio, Cochran Q and $\mathrm{I}^{2}$ values, as well as and to produce Forest plots and Bias-assessment plots.

\section{ACKNOWLEDGMENTS}

We thank Prof Pascal Dumont (Tours Hospital) and Valérie Gissot (CIC INSERM 1415) for their help in collecting tissues and clinical data. English was edited by Alex Edelman \& Associates.

\section{CONFLICTS OF INTEREST}

None.

\section{GRANT SUPPORT}

N.HV and V.GG received financial supports from the French Higher Education and Research Ministry under the program "Investissements d'avenir", Grant agreement:, and from the European Union (Grant Agreement: Presage 4940-37478; OutExFon). Europe is engaged in Région Centre with the FEDER. N.B fellowship was obtained from LabEX MAbImprove ANR-10-LABX-53-01, the one for E.D from Région Centre (BIOSONS project), the one for D.C.C from both LabEX MAbImprove ANR-10LABX-53-01 and Région Centre.

\section{REFERENCES}

1. Domagala-Kulawik J. The role of the immune system in non-small cell lung carcinoma and potential for therapeutic intervention. Transl Lung Cancer Res. 2015; 4: 177-90. doi: 10.3978/j.issn.2218-6751.2015.01.11.

2. Alifano M, Mansuet-Lupo A, Lococo F, Roche N, Bobbio A, Canny E, Schussler O, Dermine H, Régnard J-F, Burroni B, Goc J, Biton J, Ouakrim H, et al. Systemic inflammation, nutritional status and tumor immune microenvironment determine outcome of resected non-small cell lung cancer. PloS One. 2014; 9: e106914. doi: 10.1371/journal. pone. 0106914 .

3. Germain C, Gnjatic S, Tamzalit F, Knockaert S, Remark R, Goc J, Lepelley A, Becht E, Katsahian S, Bizouard G, Validire P, Damotte D, Alifano M, et al. Presence of $\mathrm{B}$ cells in tertiary lymphoid structures is associated with a protective immunity in patients with lung cancer. Am J Respir Crit Care Med. 2014; 189: 832-44. doi: 10.1164/ rccm.201309-16110C.

4. Fucikova J, Becht E, Iribarren K, Goc J, Remark R, Damotte D, Alifano M, Devi P, Biton J, Germain C, Lupo A, Fridman WH, Dieu-Nosjean M-C, et al. Calreticulin Expression in Human Non-Small Cell Lung Cancers Correlates with Increased Accumulation of Antitumor Immune Cells and Favorable Prognosis. Cancer Res. 2016; doi: 10.1158/0008-5472.CAN-15-1142.

5. Roopenian DC, Akilesh S. FcRn: the neonatal Fc receptor comes of age. Nat Rev Immunol. 2007; 7: 715-25. doi: $10.1038 /$ nri2155.

6. Ward ES, Ober RJ. Chapter 4: Multitasking by exploitation of intracellular transport functions the many faces of FcRn. Adv Immunol. 2009; 103: 77-115. doi: 10.1016/ S0065-2776(09)03004-1.

7. Claypool SM, Dickinson BL, Wagner JS, Johansen F-E, Venu N, Borawski JA, Lencer WI, Blumberg RS. Bidirectional transepithelial IgG transport by a strongly polarized basolateral membrane Fegamma-receptor. Mol Biol Cell. 2004; 15: 1746-59. doi: 10.1091/mbc. E03-11-0832.

8. Junghans RP, Anderson CL. The protection receptor for IgG catabolism is the beta2-microglobulin-containing neonatal intestinal transport receptor. Proc Natl Acad Sci U S A. 1996; 93: 5512-6.

9. Roopenian DC, Christianson GJ, Sproule TJ, Brown AC, Akilesh S, Jung N, Petkova S, Avanessian L, Choi EY, Shaffer DJ, Eden PA, Anderson CL. The MHC class I-like IgG receptor controls perinatal IgG transport, IgG homeostasis, and fate of IgG-Fc-coupled drugs. J Immunol Baltim Md 1950. 2003; 170: 3528-33. 
10. Ben Suleiman Y, Yoshida M, Nishiumi S, Tanaka H, Mimura T, Nobutani K, Yamamoto K, Takenaka M, Aoganghua A, Miki I, Ota H, Takahashi S, Matsui H, et al. Neonatal Fc receptor for $\operatorname{IgG}(\mathrm{FcRn})$ expressed in the gastric epithelium regulates bacterial infection in mice. Mucosal Immunol. 2012; 5: 87-98. doi: 10.1038/mi.2011.53.

11. Yoshida M, Kobayashi K, Kuo TT, Bry L, Glickman JN, Claypool SM, Kaser A, Nagaishi T, Higgins DE, Mizoguchi E, Wakatsuki Y, Roopenian DC, Mizoguchi A, et al. Neonatal Fc receptor for IgG regulates mucosal immune responses to luminal bacteria. J Clin Invest. 2006; 116: 2142-51. doi: 10.1172/JCI27821.

12. Bai Y, Ye L, Tesar DB, Song H, Zhao D, Björkman PJ, Roopenian DC, Zhu X. Intracellular neutralization of viral infection in polarized epithelial cells by neonatal $\mathrm{Fc}$ receptor (FcRn)-mediated IgG transport. Proc Natl Acad Sci U S A. 2011; 108: 18406-11. doi: 10.1073/pnas.1115348108.

13. Ko S-Y, Pegu A, Rudicell RS, Yang Z, Joyce MG, Chen X, Wang K, Bao S, Kraemer TD, Rath T, Zeng M, Schmidt $\mathrm{SD}$, Todd J-P, et al. Enhanced neonatal Fc receptor function improves protection against primate SHIV infection. Nature. 2014; 514: 642-5. doi: 10.1038/nature13612.

14. Zhu X, Meng G, Dickinson BL, Li X, Mizoguchi E, Miao L, Wang Y, Robert C, Wu B, Smith PD, Lencer WI, Blumberg RS. MHC class I-related neonatal Fc receptor for IgG is functionally expressed in monocytes, intestinal macrophages, and dendritic cells. J Immunol Baltim Md 1950. 2001; 166: 3266-76.

15. Vidarsson G, Stemerding AM, Stapleton NM, Spliethoff SE, Janssen H, Rebers FE, de Haas M, van de Winkel JG. FcRn: an IgG receptor on phagocytes with a novel role in phagocytosis. Blood. 2006; 108: 3573-9. doi: 10.1182/ blood-2006-05-024539.

16. Qiao S-W, Kobayashi K, Johansen F-E, Sollid LM, Andersen JT, Milford E, Roopenian DC, Lencer WI, Blumberg RS. Dependence of antibody-mediated presentation of antigen on FcRn. Proc Natl Acad Sci U S A. 2008; 105: 9337-42. doi: 10.1073/pnas.0801717105.

17. Baker K, Qiao S-W, Kuo TT, Aveson VG, Platzer B, Andersen J-T, Sandlie I, Chen Z, de Haar C, Lencer WI, Fiebiger E, Blumberg RS. Neonatal Fc receptor for $\operatorname{IgG}(\mathrm{FcRn})$ regulates cross-presentation of IgG immune complexes by CD8CD11b+ dendritic cells. Proc Natl Acad Sci U S A. 2011; 108: 9927-32. doi: 10.1073/pnas.1019037108.

18. Baker K, Rath T, Flak MB, Arthur JC, Chen Z, Glickman JN, Zlobec I, Karamitopoulou E, Stachler MD, Odze RD, Lencer WI, Jobin C, Blumberg RS. Neonatal Fc receptor expression in dendritic cells mediates protective immunity against colorectal cancer. Immunity. 2013; 39: 1095-107. doi: 10.1016/j.immuni.2013.11.003.

19. Sörenson S, Glimelius B, Nygren P, SBU-group. Swedish Council of Technology Assessment in Health Care. A systematic overview of chemotherapy effects in nonsmall cell lung cancer. Acta Oncol Stockh Swed. 2001; 40: $327-39$.
20. Spiekermann GM, Finn PW, Ward ES, Dumont J, Dickinson BL, Blumberg RS, Lencer WI. Receptor-mediated immunoglobulin $\mathrm{G}$ transport across mucosal barriers in adult life: functional expression of FcRn in the mammalian lung. J Exp Med. 2002; 196: 303-10.

21. Román-Pérez E, Casbas-Hernández P, Pirone JR, Rein J, Carey LA, Lubet RA, Mani SA, Amos KD, Troester MA. Gene expression in extratumoral microenvironment predicts clinical outcome in breast cancer patients. Breast Cancer Res. 2012; 14: R51. doi: 10.1186/bcr3152.

22. Lamb JR, Zhang C, Xie T, Wang K, Zhang B, Hao K, Chudin E, Fraser HB, Millstein J, Ferguson M, Suver C, Ivanovska I, Scott M, et al. Predictive genes in adjacent normal tissue are preferentially altered by $\mathrm{sCNV}$ during tumorigenesis in liver cancer and may rate limiting. PloS One. 2011; 6: e20090. doi: 10.1371/journal. pone.0020090.

23. Rhodes DR, Yu J, Shanker K, Deshpande N, Varambally R, Ghosh D, Barrette T, Pandey A, Chinnaiyan AM. ONCOMINE: a cancer microarray database and integrated data-mining platform. Neoplasia. 2004; 6: 1-6.

24. Győrffy B, Surowiak P, Budczies J, Lánczky A. Online survival analysis software to assess the prognostic value of biomarkers using transcriptomic data in non-small-cell lung cancer. PloS One. 2013; 8: e82241. doi: 10.1371/journal. pone. 0082241.

25. Mizuno H, Kitada K, Nakai K, Sarai A. PrognoScan: a new database for meta-analysis of the prognostic value of genes. BMC Med Genomics. 2009; 2: 18. doi: 10.1186/1755-8794-2-18.

26. Goswami CP, Nakshatri H. PROGgeneV2: enhancements on the existing database. BMC Cancer. 2014; 14: 970. doi: 10.1186/1471-2407-14-970.

27. Aguirre-Gamboa R, Gomez-Rueda H, Martínez-Ledesma E, Martínez-Torteya A, Chacolla-Huaringa R, RodriguezBarrientos A, Tamez-Peña JG, Treviño V. SurvExpress: an online biomarker validation tool and database for cancer gene expression data using survival analysis. PloS One. 2013; 8: e74250. doi: 10.1371/journal. pone. 0074250 .

28. Freiberger T, Grodecká L, Ravcuková B, Kurecová B, Postránecká V, Vlcek J, Jarkovský J, Thon V, Litzman J. Association of FcRn expression with lung abnormalities and IVIG catabolism in patients with common variable immunodeficiency. Clin Immunol Orlando Fla. 2010; 136: 419-25. doi: 10.1016/j.clim.2010.05.006.

29. Gomperts BN, Spira A, Massion PP, Walser TC, Wistuba II, Minna JD, Dubinett SM. Evolving concepts in lung carcinogenesis. Semin Respir Crit Care Med. 2011; 32: 32-43. doi: 10.1055/s-0031-1272867.

30. Santarpia M, Giovannetti E, Rolfo C, Karachaliou N, González-Cao M, Altavilla G, Rosell R. Recent developments in the use of immunotherapy in non-small cell lung cancer. Expert Rev Respir Med. 2016; doi: 10.1080/17476348.2016.1182866. 
31. Soria J-C, Marabelle A, Brahmer JR, Gettinger S. Immune checkpoint modulation for non-small cell lung cancer. Clin Cancer Res. 2015; 21: 2256-62. doi: 10.1158/1078-0432. CCR-14-2959.

32. Wang J, Wu N, Zheng Q, Feng Y, Yan S, Lv C, Li S, Wang Y, Yang Y. Evaluation of the 7th edition of the TNM classification for lung cancer at a single institution. J Cancer Res Clin Oncol. 2014; 140: 1189-95. doi: 10.1007/ s00432-014-1636-0.

33. Heinrich EL, Walser TC, Krysan K, Liclican EL, Grant JL, Rodriguez NL, Dubinett SM. The inflammatory tumor microenvironment, epithelial mesenchymal transition and lung carcinogenesis. Cancer Microenviron. 2012; 5: 5-18. doi: 10.1007/s12307-011-0089-0.

34. Galon J, Mlecnik B, Bindea G, Angell HK, Berger A, Lagorce C, Lugli A, Zlobec I, Hartmann A, Bifulco C, Nagtegaal ID, Palmqvist R, Masucci GV, et al. Towards the introduction of the "Immunoscore" in the classification of malignant tumours. J Pathol. 2014; 232: 199-209. doi: 10.1002/path.4287.

35. Anitei M-G, Zeitoun G, Mlecnik B, Marliot F, Haicheur N, Todosi A-M, Kirilovsky A, Lagorce C, Bindea G, Ferariu D, Danciu M, Bruneval P, Scripcariu V, et al. Prognostic and predictive values of the immunoscore in patients with rectal cancer. Clin Cancer Res. 2014; 20: 1891-9. doi: 10.1158/1078-0432.CCR-13-2830.

36. Gueugnon F, Barascu A, Mavridis K, Petit-Courty A, Marchand-Adam S, Gissot V, Scorilas A, Guyetant S, Courty Y. Kallikrein-related peptidase 13: an independent indicator of favorable prognosis for patients with nonsmall cell lung cancer. Tumour Biol J. 2015; doi: 10.1007/ s13277-015-3148-1.
37. Vandesompele J, De Preter K, Pattyn F, Poppe B, Van Roy N, De Paepe A, Speleman F. Accurate normalization of real-time quantitative RT-PCR data by geometric averaging of multiple internal control genes. Genome Biol. 2002; 3: RESEARCH0034.

38. DeLong ER, DeLong DM, Clarke-Pearson DL. Comparing the areas under two or more correlated receiver operating characteristic curves: a nonparametric approach. Biometrics. 1988; 44: 837-45.

39. Beer DG, Kardia SLR, Huang C-C, Giordano TJ, Levin AM, Misek DE, Lin L, Chen G, Gharib TG, Thomas DG, Lizyness ML, Kuick R, Hayasaka S, et al. Gene-expression profiles predict survival of patients with lung adenocarcinoma. Nat Med. 2002; 8: 816-24. doi: 10.1038/nm733.

40. Garber ME, Troyanskaya OG, Schluens K, Petersen S, Thaesler Z, Pacyna-Gengelbach M, van de Rijn M, Rosen GD, Perou CM, Whyte RI, Altman RB, Brown PO, Botstein $\mathrm{D}$, et al. Diversity of gene expression in adenocarcinoma of the lung. Proc Natl Acad Sci U S A. 2001; 98: 13784-9. doi: 10.1073/pnas.241500798.

41. Zhu C-Q, Ding K, Strumpf D, Weir BA, Meyerson M, Pennell N, Thomas RK, Naoki K, Ladd-Acosta C, Liu N, Pintilie M, Der S, Seymour L, et al. Prognostic and predictive gene signature for adjuvant chemotherapy in resected non-small-cell lung cancer. J Clin Oncol. 2010; 28: 4417-24. doi: 10.1200/JCO.2009.26.4325.

42. Hou J, Aerts J, den Hamer B, van Ijcken W, den Bakker M, Riegman P, van der Leest C, van der Spek P, Foekens JA, Hoogsteden HC, Grosveld F, Philipsen S. Gene expressionbased classification of non-small cell lung carcinomas and survival prediction. PloS One. 2010; 5: e10312. doi: 10.1371/journal.pone.0010312. 